\title{
PENGARUH METODE QUANTUM LEARNING TERHADAP MINAT BELAJAR SISWA DAN PENGUASAAN KONSEP BIOLOGI KELAS VIII SMP NEGERI 11 BANDAR LAMPUNG
}

\author{
${ }^{1}$ Bambang S. A, ${ }^{2}$ Akbar Handoko dan ${ }^{3}$ Indri Andriyani \\ 1,2,3 Universitas Islam Negeri Raden Intan Lampung.Jl. H Endro Suratmin Sukarame- \\ Bandar Lampung (0721)70326): akbar.handoko@radenintan.ac.id
}

Diterima : 07 Agustus 2017. Disetujui: 15 Desember 2017. Dipublikasikan: 29 Desember 2017

\begin{abstract}
Abstrak
Penelitian dilakukan di SMP Negeri 11 Bandar Lampung yang bertempat di Jl. Sentot Kel. Ketapang Kec. Panjang Bandar Lampung. Permasalahan rendahnya nilai biologi siswa disebabkan kurang aktifnya siswa dalam proses belajar mengajar, selain itu disebabkan karena proses pembelajaran biologi masih berorientasi pada guru (Teacher Centered), sehingga minat belajar siswa dan penguasaan konsep biologi masih rendah. Penelitian ini bertujuan untuk mengetahui pengaruh metode pembelajaran quantum learning terhadap penguasaan konsep biologi siswa kelas VIII SMPN11 Bandar Lampung pada konsep sistem pencernaan dan untuk mengetahui pengaruh metode pembelajaran quantum learning terhadap minat belajar siswa kelas VIII SMPN 11 Bandar Lampung pada konsep sistem pencernaaan.

Desain penelitian yang digunakan adalah The Matching only posttest control group design. Alat pengumpulan data yang digunakan adalah tes, angket, lembar diskusi siswa dan dokumentasi. Instrumen penelitian terdiri dari tes penguasaan konsep biologi, angket minat belajar siswa. Hasil penelitian berupa data kuantitatif, data yang digunakan dalam penelitian yaitu tes berupa nilai posttest dan nilai angket. Nilai posttest digunakan untuk mengetahui nilai penguasaan konsep pada ranah kognitif dan nilai angket untuk mengetahui minat belajar siswa pada ranah afektif. Uji hipotesis penelitian menggunakan uji $t$ dimana, sebelum dilakukan uji $t$ data di uji terlebih dahulu menggunakan uji prasyarat yaitu uji normalitas dan uji homogenitas.

Dari hasil penelitian didapatkan bahwa penguasaan konsep biologi dengan menggunakan metode quantum learning kelas eksperimen diperoleh nilai posttest rata-rata 76,14 dan pada kelas kontrol diperoleh nilai rata-rata 70,73. Sedangkan jika dilihat dari setiap indikator minat belajar siswa terjadi peningkatan. Dari perhitungan nilai minat belajar siswa, diketahui bahwa persentase dari setiap indikator kelas eksperimen dan kelas kontrol terdapat perbedaan. Pada kelas eksperimen didapatkan persentase lebih tinggi dari pada kelas kontrol. Untuk uji $t$ pada posttest diperoleh $\mathrm{t}_{\text {hitung }}=5,6170 \mathrm{t}_{\text {tabel }(0,05)}=1,6602$ dan pada uji $t$ pada angket diperoleh $\mathrm{t}_{\text {hitung }}$ $5,8334 \mathrm{t}_{\text {tabel }}=1,6602$. Dengan demikian apabila $\mathrm{t}_{\text {hitung }}>\mathrm{t}_{\text {tabel }}$ maka $\mathrm{H}_{1}$ diterima dan $\mathrm{H}_{0}$ ditolak. Jadi dapat disimpulkan bahwa metode pembelajaran quantum learning berpengaruh positif terhadap penguasaan konsep biologi dan minat belajar siswa.
\end{abstract}

Kata kunci: Metode Pembelajaran Quantum Learning, minat belajar siswa, penguasaan konsep biologi. 


\section{PENDAHULUAN}

Dalam era globalisasi, tantangan persaingan diberbagai bidang kehidupan semakin ketat. Ketatnya persaingan ditandai dengan adanya perubahan lingkungan dan masyarakat yang cepat dengan kemajuan teknologi informasi yang menuntut kepekaan Negara, pemerintah dan masyarakat dalam merespon perubahan supaya tetap eksis dalam menghadapi persaingan dunia. Menghadapi tantangan era globalisasi dibutuhkan sumber daya manusia yang berkualitas, sumber daya manusia yang berkualitas salah satunya dapat dilihat dari kualitas pendidikannya. Kesadaran tentang pentingnya pendidikan telah mendorong berbagai upaya dan perhatian seluruh lapisan masyarakat terhadap setiap perkembangan dunia pendidikan.

Pendidikan merupakan suatu proses jangka panjang yang sudah menjadi bagian yang tidak terpisahkan dalam kehidupan di dunia, sebab hanya melalui proses pendidikan yang baik, maka manusia mampu meraih dan menguasai ilmu pengetahuan untuk bekal hidupnya. Pendidikan adalah suatu proses dalam rangka mempengaruhi siswa supaya mampu menyesuaikan diri sebaik mungkin dalam lingkungannya dan dengan demikian dapat menimbulkan perubahan dalam masyarakat (Oemar Hamalik, 2009). Pendidikan membuat manusia berusaha mengembangkan dirinya sehingga mampu menghadapi setiap perubahan yang terjadi akibat adanya kemajuan ilmu pengetahuan dan teknologi.

Pendidikan nasional berfungsi untuk mengembangkan kemampuan dan membentuk watak serta peradaban bangsa yang bermartabat dalam rangka mencerdaskan kehidupan bangsa. Belajar merupakan salah satu upaya guna mencerdaskan kehidupan bangsa. Belajar pada hakekatnya adalah perubahan yang terjadi dalam diri seseorang setelah berakhirnya melakukan aktifitas belajar, walaupun 
pada kenyataannya tidak semua perubahan termasuk kategori belajar (Syaiful Bahri Djamarah, 2012). Proses belajar merupakan jalan yang harus ditempuh oleh seorang manusia untuk mengerti suatu hal yang sebelumnya tidak diketahui. Seseorang yang melakukan kegiatan belajar dapat dikatakan telah mengerti suatu hal apabila ia juga dapat menerapkan apa yang telah ia pelajari.

Salah satu prinsip yang penting dalam proses pembelajaran adalah guru tidak hanya semata-mata memberi pengetahuan pada siswa, guru memegang peranan dalam melaksanakan proses belajar mengajar. Pengertian mengajar sebagai suatu kegiatan penyampaian bahan pelajaran kepada pelajar supaya dapat menerima, menanggapi, menguasai, dan mengembangkan bahan pelajaran itu (Ramayulis, 2012). Dalam mengajar guru harus mampu menciptakan suasana kondusif supaya menambah interaksi dan keikutsertaan siswa dalam belajar, karena siswa sendirilah yang seharusnya membangun pengetahuannya. Guru dapat membantu proses pembelajaran dengan cara memilih alternatif mengajar yang membuat informasi menjadi sangat bermakna dan relevan bagi siswa. Guru perlu menguasai keterampilan, cara kerja dan pengetahuan dalam bidangnya.

Penguasaan metode pembelajaran yang bervariatif sangat diperlukan guru untuk dapat meningkatkan penguasaan konsep dan minat belajar siswa. Metode pembelajaran yang bervariatif dapat membuat siswa aktif memahami konsep. Namun, pada kenyataannya berdasarkan hasil observasi guru lebih dominan menguasai kegiatan pembelajaran. Siswa cenderung pasif selama kegiatan pembelajaran. Guru mewajibkan siswa untuk menghafal materi tetapi tidak mengajarkan siswa untuk memahami materi. Kecakapan siswa dalam memahami materi sangat diperlukan karena hal itu berpengaruh pada hasil belajar siswa dan penguasaan konsep pada siswa (Robert S. 
Slavin, 2013). Siswa dapat dikatakan memahami suatu konsep apabila sudah dapat menjelaskan dengan menggunakan kalimatnya sendiri.

Pada pembelajaran IPA khususnya Biologi, penguasaan konsep sangat penting. Penguasaan konsep yang baik membuat siswa dapat berpikir pada tingkatan yang lebih tinggi lagi. Konsep adalah sekumpulan atau seperangkat sifat yang dihubungkan oleh aturan-aturan tertentu dan konsep merupakan bayangan mental, ide dan proses (Hulse, 2010). Konsep juga adalah pembentukan mental dalam mengelompokkan kata-kata dengan penjelasan tertentu yang dapat diterima secara umum (Nuryani R, 2003). Jadi dapat disimpulkan bahwa konsep adalah suatu gagasan yang dapat menggambarkan suatu kejadian atau ciri-ciri. Penguasaan konsep yang baik pun semestinya mempermudah siswa dalam mencapai kriteria ketuntasan minimal (KKM) yang telah ditetapkan oleh sekolah. Dalam usaha meningkatkan penguasaan konsep IPA Biologi di sekolah, guru seharusnya kreatif dan inovatif dalam menggunakan metode pembelajaran. Penggunaan metode pembelajaran dapat mempermudah siswa dalam proses belajar membangun pengetahuannya.

Guna tercapainya penguasaan konsep dan minat belajar dilakukan proses pembelajaran yang efektif. Pembelajaran yang efektif dapat membantu siswa untuk meningkatkan kemampuan yang diharapkan sesuai dengan tujuan instruksional yang didapat (Slameto, 2013). Pembelajaran yang efektif adalah pembelajaran yang menyediakan kesempatan belajar sendiri atau melakukan aktivitas sendiri. Pembelajaran yang efektif juga akan melatih dan menanamkan sikap demokratis bagi siswa dan juga dapat menciptakan suasana pembelajaran yang menyenangkan sehingga memberikan kreatifitas siswa untuk mampu belajar dengan potensi yang sudah siswa miliki yaitu 
dengan memberikan kebebasan dalam melaksanakan pembelajaran dengan cara belajarnya sendiri.

Tercapainya pembelajaran yang efektif tergantung dari proses penyelenggaraan proses pembelajaran yang dilakukan. Penyelenggaraan pembelajaran yang dilakukan salah satu faktor penentunya yaitu guru. Guru memiliki pengaruh yang sangat besar terhadap keberhasilan peserta didik. Kualitas dan keberhasilan pembelajaran yang dilakukan sangat dipengaruhi oleh kemampuan dan ketepatan guru dalam memilih, menyampaikan, menggunakan berbagai sarana, serta metode pembelajaran yang digunakan. Metode merupakan cara yang dipergunakan oleh guru dalam mengajarkan siswa saat berlangsungnya proses pembelajaran (Ramayulis, 2002). Metode yang digunakan dalam pembelajaran biologi diharapkan dapat menumbuhkan interaksi antara guru dengan siswa dan siswa dengan siswa maupun sebaliknya, sehingga guru dan siswa saling belajar dan dapat menumbuhkan kerjasama kelas sehingga tercapai kelas yang nyaman sebagai tempat untuk belajar.

Salah satu metode pembelajaran yang dapat disesuaikan untuk meningkatkan penguasaan konsep dan minat belajar siswa adalah dengan menggunakan metode quantum learning. Dengan penerapan metode quantum learning, yang memiliki keunggulan yaitu dari gaya belajar yang membebaskan siswa (Bobbi Depoorter \& Mike Hernacki, 2013).

\section{METODE PENELITIAN}

Desain yang digunakan dalam penelitian ini adalah The Matching only posttest control group design. Dalam pola ini baik eksperimen maupun kontrol dikenakan posttest, tetapi hanya kelompok eksperimen yang mendapat perlakuan (Freankel JR and Wallen NE, 2008). Sampel yang diambil dalam penelitian terdiri dari dua kelas, yaitu 
kelas VIII C sebagai kelas eksperimen dan kelas VIII A sebagai kelas kontrol. Teknik yang digunakan dalam penelitian adalah menggunakan Sampling acak sederhana yaitu mencampur subjek-subjek didalam populasi sehingga semua subjek dianggap sama (Suharsimi Arikunto, 2006). Dengan demikian maka peneliti memberi hak yang sama kepada subjek untuk memperoleh kesempatan dipilih menjadi sampel. Analisis data penelitian menggunakan uji t independent.

\section{HASIL PENELITIAN}

Hasil penelitian ini menunjukkan bahwa $t_{\text {hitung }}>t_{\text {tabel }}$ yang berarti $H_{1}$ diterima dan $\mathrm{H}_{\mathrm{O}}$ ditolak. Hal tersebut menunjukkan bahwa terdapat pengaruh signifikan penggunaan metode quantum learning terhadap minat belajar siswa dan penguasaan konsep biologi. Hasil perhitungan data menggunakan uji $t$ independent pada penelitian disajikan pada tabel dibawah ini

Tabel 1.

Hasil Perhitungan Uji $t$ Angket Minat Belajar

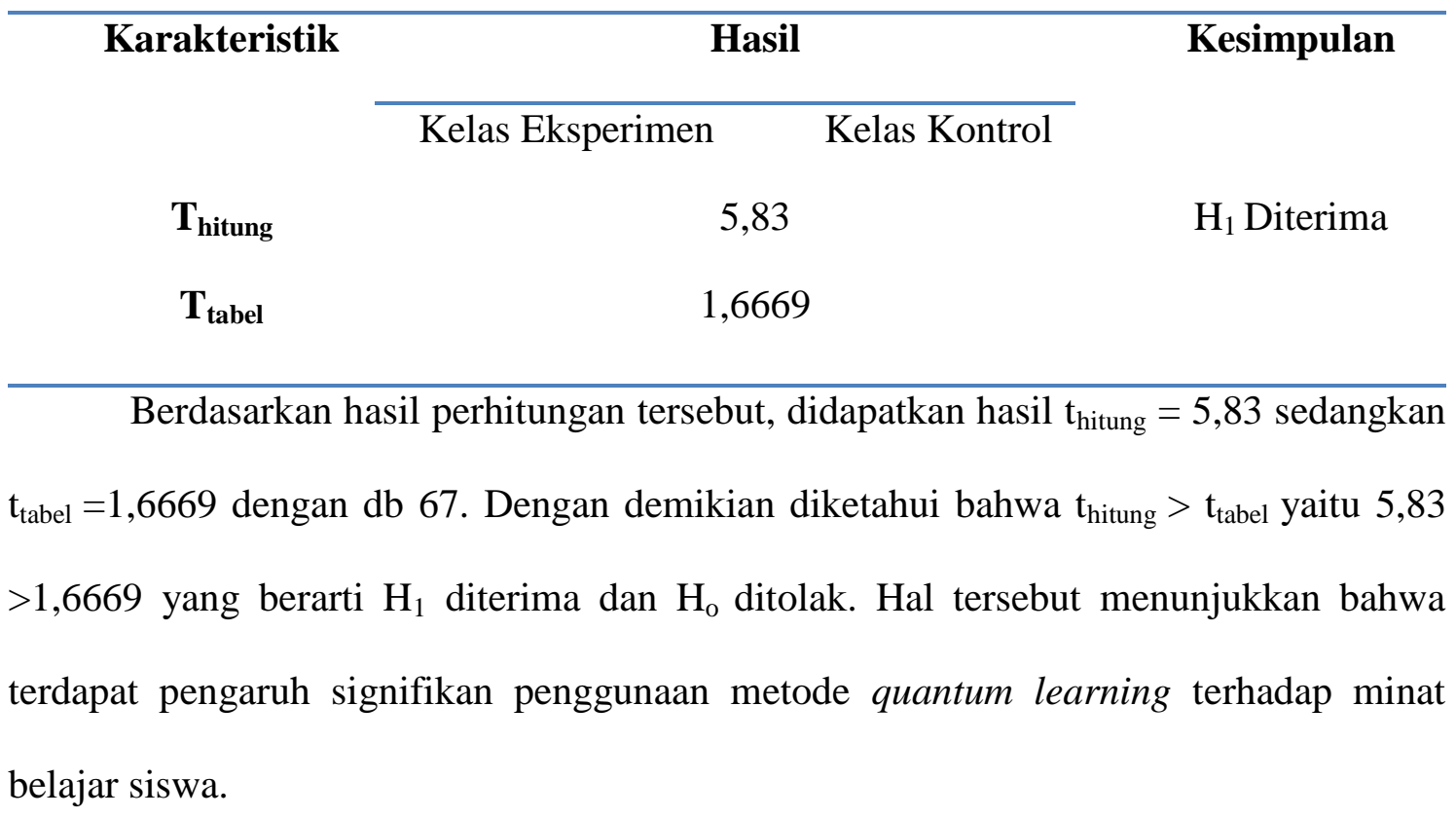


Tabel 2.

Hasil Perhitungan Uji $t$ Tes Penguasaan Konsep

\begin{tabular}{|c|c|c|}
\hline Karakteristik & Hasil & Kesimpulan \\
\hline & Kelas Eksperimen & \\
\hline $\mathbf{T}_{\text {hitung }}$ & 12,97 & $\mathrm{H}_{1}$ Diterima \\
\hline $\mathbf{T}_{\text {tabel }}$ & 1,6669 & \\
\hline
\end{tabular}

Dari perhitungan tersebut didapatkan hasil $t_{\text {hitung }}=12,97$ sedangkan $t_{\text {tabel }}=$ 1,6669 dengan db 67. Dengan demikian diketahui bahwa $t_{\text {hitung }}>t_{\text {tabel }}$ yaitu 12,97 >1,6669 yang berarti $\mathrm{H}_{1}$ diterima dan $\mathrm{H}_{\mathrm{O}}$ ditolak. Hal tersebut menunjukkan bahwa terdapat pengaruh signifikan penggunaan metode quantum learning terhadap penguasaan konsep biologi.

Berdasarkan analisis data angket minat belajar yang diperoleh, peningkatan dari setiap indikator minat belajar siswa kelas eksperimen dan kelas kontrol dapat dilihat pada tabel berikut:

Tabel 3.

Nilai Rata-Rata Setiap Indikator Minat Belajar Pada Kelas Eksperimen Dan Kelas Kontrol

\begin{tabular}{rllc}
\hline No. & Indikator Minat & $\begin{array}{c}\text { Kelas } \\
\text { Eksperimen }\end{array}$ & Kelas Kontrol \\
\hline 1. & Perasaan Senang & $98,09 \%$ & $95,11 \%$ \\
2. & Ketertarikan Siswa & $81,63 \%$ & $77,82 \%$ \\
3. & Perhatian Siswa & $73,48 \%$ & $63,11 \%$ \\
4. & Keterlibatan Siswa & $40,83 \%$ & $34,58 \%$ \\
\hline
\end{tabular}

Berdasarkan perhitungan nilai minat belajar siswa, diketahui bahwa persentase dari setiap indikator diatas pada kelas eksperimen dan kelas kontrol terdapat perbedaan. Perbedaan tersebut setelah minat belajar siswa menggunakan metode quantum learning. 
Metode quantum learning mempengaruhi setiap indikator minat belajar siswa lebih besar daripada minat belajar siswa pada kelas kontrol.

\section{PEMBAHASAN}

Berdasarkan hasil perhitungan diketahui rata-rata nilai akhir siswa kelas eksperimen berbeda signifikan dengan kelas kontrol. Pada kelas eksperimen dalam proses pembelajaran menggunakan metode quantum learning diperoleh nilai rata-rata 76,14. Sedangkan pada kelas kontrol yang menggunakan metode pembelajaran ceramah diperoleh rata-rata 70,73 . Hal ini menunjukkan bahwa pembelajaran menggunakan metode quantum learning memberikan pengaruh terhadap hasil belajar kognitif siswa.

Peningkatan penguasaan konsep biologi ini disebabkan karena kelas eksperimen menggunakan metode quantum learning yang mana siswa belajar dengan gaya belajar yang mereka sukai. Quantum learning pada kelompok eksperimen mengakomodasi siswa dengan gaya belajar visual melalui tulisan dan lembar diskusi siswa yang disertai gambar-gambar yang berwarna. Siswa dengan gaya belajar auditori diakomodasi melalui penyampaian konsep dengan intonasi yang jelas dan guru juga memberikan penekanan suara pada beberapa kalimat penting. Sedangkan siswa kinestetik diakomodasi dengan diskusi kelompok agar mereka bisa selalu berinteraksi dengan teman-temannya.

Selain hasil tes penguasaan konsep, peneliti juga meneliti minat belajar siswa. Dengan menggunakan indikator minat belajar yang dikembangkan oleh safari yaitu perasaan senang, ketertarikan siswa, perhatian siswa dan keterlibatan siswa (Safari, 2005). Dalam menilai minat belajar digunakan angket minat belajar siswa. Angket minat belajar dijadikan sebagai nilai pokok minat belajar siswa. Selanjutnya nilai angket minat belajar yang telah diperoleh akan dikonveksikan yang terdiri dari sangat setuju, 
setuju, tidak setuju dan sangat tidak setuju (Suharsimi Arikunto, 2013). Hasil perhitungan uji-t diketahui bahwa $\mathrm{t}_{\text {hitung }}>\mathrm{t}_{\text {tabel }}$ yaitu $5,8334>1,6669$ yang berarti $\mathrm{H}_{1}$ diterima dan $\mathrm{H}_{0}$ ditolak. Hal tersebut menunjukkan bahwa ada pengaruh signifikan penggunaan metode quantum learning terhadap minat belajar siswa.

Hasil penelitian menunjukkan bahwa penguasaan konsep biologi dan minat belajar siswa yang menggunakan metode quantum learning lebih tinggi dari pada hasil penguasaan konsep biologi dan minat belajar yang menggunakan metode ceramah. Perbedaan hasil yang diperoleh antara kelas eksperimen dan kelas kontrol terjadi karena telah diterapkannya metode quantum learning. Berdasarkan hasil observasi yang dilakukan peneliti terhadap siswa selama proses pembelajaran berlangsung menunjukkan perbedaan aktivitas siswa yaitu: (1) semua siswa mengikuti kegiatan belajar mengajar dengan tekun dan sungguh-sungguh, (2) semua siswa terlibat dalam memahami materi pelajaran, (3) terjadi peningkatan keaktifan siswa dalam mengemukakan pendapat, komentar dan pertanyaan, dan (4) semua siswa aktif dalam berdiskusi dan berkerjasama dalam kelompok. Perbedaan keaktifan dan kreativitas siswa terjadi karena pembelajaran melalui metode quantum learning sangat disukai siswa. Siswa menyukai metode quantum learning karena metode pembelajaran ini memberikan kesempatan siswa untuk lebih aktif dalam pembelajaran dengan cara-cara yang menyenangkan dan tidak membosankan (Bobbi Deporter \& Mike Hernacki, 2011). Siswa diminta menyelesaikan tugasnya dalam kelompok, dimana tiap kelompok terdiri dari enam orang, siswa akan terlatih menerapkan konsep bertukarpikiran dan pendapat untuk dapat menyelesaikan masalah yang ada.

Pembelajaran berlangsung dengan suasana yang menarik, menyenangkan jauh dari kesan kaku dan menegangkan. Pembelajaran yang menyenangkan adalah pembelajaran 
yang membuat anak didik tidak takut salah, ditertawakan, diremehkan, atau merasa tertekan (Aquillaningtyas Septawulan, 2012). Dalam hal ini, guru dituntut untuk menciptakan kondisi pembelajaran sedemikian rupa sehingga siswa menjadi betah belajar karena pembelajaran yang dijalani menyenangkan dan bermakna. Pembelajaran menyenangkan juga berarti pembelajaran yang interaktif dan menarik, sehingga siswa dapat memusatkan perhatian terhadap pembelajaran yang sedang dijalananinya (Bobbi Deporter \& Mike Hernacki, 2011). Proses pembelajaran quantum learning yang dilakukan dapat mengubah situasi belajar yang membosankan menjadi menarik sehingga dapat merangsang siswa untuk aktif berdiskusi, berlatih berbahasa, berfikir secara kritis, logis dan kreatif. Dengan menerapkan metode quantum learning telah meningkatkan keaktifan siswa dalam menyampaikan pendapat, baik bertanya maupun menjawab pertanyaan. Metode pembelajaran quantum learning yaitu menciptakan suasana yang menimbulkan kenyamanan dan rasa santai. Keadaan santai mendorong siswa untuk dapat berkonsentrasi dengan sangat baik dan mampu belajar dengan sangat mudah (Bobbi Deporter \& Mike Hernacki, 2011)

Telah dijelaskan sebelumnya bahwa pembelajaran menggunakan metode quantum learning adalah pembelajaran dengan cara yang menyenangkan sehingga dapat mempengaruhi penguasaan konsep biologi dan minat belajar siswa. Siswa dituntut aktif dan diberikan kesempatan untuk mengasimilasi informasi tersebut dengan pengenalan konsep dan mengorganisasikan informasi tersebut sebagai aplikasi dari konsep yang didapatkan dengan begitu siswa lebih memahami materi pembelajaran yang mempengaruhi penguasaan konsep dan minat belajar yang tinggi karena siswa lebih aktif dalam proses pembelajaran. 
Hasil observasi terhadap kelas VIII C sebagai kelas eksperimen memperlihatkan bahwa kelas VIII C aktif dalam pembelajaran. Banyak siswa yang menunjukkan keseriusan dan keantusiasan dalam belajar. Meskipun demikian, ada juga siswa yang terlihat kurang aktif dalam pembelajaran. Hal ini terjadi karena sebagian siswa merasa teman sekelompoknya yang mempunyai kemampuan lebih tinggi sudah mampu menjawabnya, tanpa dibantu teman yang lain, selain itu ada juga siswa yang kurang tertarik dengan pelajaran biologi sehingga timbul keramaian dikelas. Namun secara klasikal penerapan metode quantum learning dalam pembelajaran biologi telah mampu meningkatkan partisipasi keaktifan siswa. Untuk observasi kelas kontrol terhadap kelas VIII A kurang aktif dalam pembelajaran karena siswa hanya mendengarkan penjelasan guru. Berdasarkan pembahasan tersebut dapat disimpulkan bahwa metode quantum learning berpengaruh terhadap minat belajar siswa dan penguasaan konsep biologi.

\section{SIMPULAN DAN SARAN}

Hasil penelitian ini menunjukkan bahwa penggunaan metode quantum learning berpengaruh terhadap minat belajar siswa kelas VIII pada materi sistem pencernaan dan penggunaan metode quantum learning berpengaruh terhadap penguasaan konsep biologi VIII pada materi sistem pencernaan manusia.

Berdasarkan hasil penelitian yang dilakukan tentang metode pembelajaran quantum learning untuk meningkatkan minat belajar siswa dan penguasaan konsep biologi kelas VIII SMPN 11 Bandar Lampung, maka penulis menggambarkan beberapa saran yang dapat digunakan sebagai tindak lanjut hasil penelitian ini yaitu: Guru hendaknya disamping menggunakan metode ceramah, guru juga perlu menggunakan metode quantum learning dalam proses belajar mengajar untuk meningkatkan hasil belajar penguasaan konsep kedepannya, pihak sekolah hendaknya lebih memperhatikan 
pengajar dan siswa, supaya dapat memperbaiki proses belajar mengajar serta hasil belajar lebih meningkat seperti dengan menggunakan metode quantum learning. Kepada peneliti lain, dapat melakukan penelitian serupa pada pokok bahasan lain, sehingga diperoleh informasi lebih luas tentang keafektifan metode quantum learning dalam pembelajaran biologi pada siswa, serta peneliti lain harus membuat permainan yang lebih menarik dan sugesti dalam proses belajar mengajar dan membuat suasana yang lebih nyaman dalam menerima materi yang diberikan guru.

\section{DAFTAR PUSTAKA}

Anas Sudijono. Pengantar Evaluasi Pendidikan. Jakarta: Raja Grafindo Persada, 2013.

Ari Widodo. Revisi Taksonomi Bloom Dan Pengembangan Butir Soal, Jurnal Penelitian Vol.4 No. 2. Bandung: FPMIPA, 2006.

Arya Setya Nugroho. Peningkatan Penguasaan Konsep Dengan Model Pembelajaran Konsep Dalam Pembelajaran IPS Sekolah Dasar. JPGSD, 2013.

Aquillaningtyas Septawulan. Belajar Biologi yang Menyenangkan dengan Permainan Kuartet dan Pemantapan Konsep secara Mandiri Melalui Blog. (Jurnal Pendidikan Penabur No. 18 Tahun ke-11), 2011.

Bambang Soerjono. Meningkatkan Minat Belajar Matematika Siswa Melalui Penerapan Metode Pembelajaran Quantum Learning Dengan Menciptakan Ruang Yang Kondusif Untuk Membangun Sugesti Siswa. (Jurnal Pendidikan Matematika STKIP PGRI Sidoarjo, vol 2. No. 1 Maret 2014 ISSN: 2337.88166), 2014.

Beni Harsono. Perbedaan Hasil Belajar Antara Metode Ceramah Konvensional Dengan Ceramah Berbantuan Media Animasi. (Jurnal ISSN Vol. 9), 2009.

Bobbi Deporter, dkk. Quantum Teaching Mempraktikkan Quantum Learning Di RuangRuang Kelas. Bandung: Kaifa, 2000.

Bobbi Deporter, Mike Hernacki. Quantum Learning Terjemahan Alwiyah. Bandung: Kaifa, 2011.

Budiyono. Statistik Untuk Penelitian. Surakarta: UNS Press, Cet Ke-3, Ed Ke-2, 2009.

Danik Margowati. Penerapan Model Pembelajaran Kolaboratif Disertai Strategi Quantum Learning Dalam Meningkatkan Hasil Belajar Biologi (Jurnal Pendidikan Universitas Sebelas Maret, Surakarta), 2009. 
Departemen Agama RI. Syaamil Al-Qur,an. Bandung: Syigma, 2007.

Depdiknas. Kurikulum Tingkat Satuan Pendidikan (KTSP), Jakarta : Departemen Pendidikan Nasional, 2006.

Depdiknas. Undang-Undang Tentang Sisdiknas dan Peraturan Pelaksanaannya 20022004. Jakarta: Tamita Utama, 2003.

Dimas Yudhistira. Upaya Meningkatkan Keterampilan Berbicara Menggunakan Metode Quantum Learning pada Siswa Kelas V SDN Karangkandri 04 Cilacap. (Jurnal Pendidikan Guru Sekolah Dasar, Universitas Negeri Yogyakarta), 2014.

Faisal Imam Prasetyo. Pengaruh Penerapan Quantum Learning Terhadap Hasil Belajar Biologi Siswa Kelas X SMA Negeri 4 Surakarta. (Jurnal Pendidikan Biologi).

Hasan Biseri. Meningkatkan Minat Belajar Matematika Siswa Melalui Penerapan Model Pembelajaran Quantum Learning dengan Menciptakan Ruang yang Kondusif untuk Membangun Sugesti Siswa. (Jurnal Pendidikan Matematika STKIP PGRI Sidoarjo), 2014.

Kusno and Purwanto. Effectiveness Of Quantum Learning For Teaching Linear Program, (International Journal For Educational Studies).

Margono. Metode Penelitian Pendidikan. Jakarta: Rineka Cipta, 2004.

Mujib Abdul. Menelusuri Psikologi dengan Menjadikan Quantum Learning sebagai Ilustrasy. (Inquiry Jurnal Ilmiah Psikologi Paramadina), Vol 2 No. 1

Munir. Penerapan Metode Pembelajaran Quantum Learning untuk Meningkatkan Hasil Belajar Siswa pada Mata Pelajaran Teknologi Informasi dan Komunikasi (TIK). (Jurnal Penerapan Pembelajaran), Vol 2.

Nuryani. Strategi Belajar Mengajar Biologi. Bandung :UPI, 2003.

Nana Sudjana. Penilaian Hasil Proses Belajar Mengajar. Bandung: Remaja Rosdakarya, 2009.

Oemar Hamalik. Kurikulum Dan Pembelajaran. Jakarta: Bumi Aksara, 2008.

Ramayulis. Ilmu Pendidikan Islam. Jakarta: Kalam Mulia, 2002.

Ratna Anggreani. Penerapan Quantum Learning Untuk Meningkatkan Hasil Belajar Siswa Pada Mata Pelajaran IPS kelas IV SDN Made II/476 surabaya,(JPGSD FIP Univeritas negeri Surabaya)

Safari. Penulisan Butir Soal Berdasarkan Penilaian Berbasis Kompetensi. Jakarta: APSI Pusat, 2005.

Santoso. A. B. Implementasi Model Pakem Dalam Meningkatkan Keterampilan Berbahasa Indonesia Siswa di Sekolah Dasar.(Jurnal Pendidikan 12(1)). 2006. 
Slameto. Belajar \& Faktor-Faktor Yamg Mempengaruhinya. Jakarta: Rineka Cipta, 2013.

Suciati Sudarisman. Memahami Hakikat Dan Krakteristik Pembelajaran Biologi Dalam Upaya Menjawab Tantangan Abad 21 Serta Optimalisasi Implementasi Kurikulum 2013. (Jurnal florae volume 2 no 1 april 2015).

Sudjana . Metode Statistika. Bandung: Tarsito, 2005. 